\title{
ANALISIS KRITIS DAMPAK INTERNET TERHADAP PERILAKU MEMBACA MAHASISWA
}

\author{
Supriyadi ${ }^{1}$ \\ M. Ridho Kholid ${ }^{2}$ \\ ${ }^{12}$ Pendidikan Biologi UIN Raden Intan Lampung \\ ${ }^{2}$ Pendidikan Bahasa Inggris UIN Raden Intan Lampung \\ E-mail: supriadi@ radenintan.ac.id
}

\begin{abstract}
This study attempts to explore students reading behavior in online and offline media, and then analyze its impact on students content recall ability and comprehension. This research uses sequential mix method approach; involving sequential qualitative and quantitative research methods. First, surveys were conducted on some samples $(N=279)$ to explore students' reading behavior profile. Second, two groups of respondents were provided (each, $N=30$ ). Group A is treated to read online, group B offline. Next, they were tested with a written test. The results of this study show that students have a dualistic tendency to choose reading media. Most of them pick and prioritize reading offline. However, on the other hand, they also like to read various online material. This choice is based on the reason that reading on online media has many options for reading materials, efficiency, convenience, low cost, and up-to-date. Interestingly, most students often get lost on searching for sources that not credible, such as Blogspot. Because, when looking for reading material, they only rely on big titles as the keyword. In terms of content recall ability and comprehension, reading material online proved to trigger a pattern of fast reading, short and not deep. This condition causes the students content to recall ability and comprehension to be lower than reading offline. Further research will be more interesting when examining how online materials influence or change students reading behavior. This is useful for lecturers as a consideration in presenting lecture materials amid the euphoria of ICT-based learning trends.
\end{abstract}

Kata Kunci: analis is krit is, internet, perilaku membaca

\section{PENDAHULUAN}

Studi

tentang

upaya meningkatkan literasi masih terus digalakkan hingga sekarang. Hal tersebut dikarenakan muncul gejala yang megindikasikan kian memudarnya budaya literasi di negara kita. Hasil studi PISA tahun 2015 menunjukkan literasi di Indonesia menempati urutan ke-69 dari 76 negara yang dinilai (OECD. 2016).
Saat ini memang ada pergeseran paradigma pada proses pendidikan di Indonesia lewat penggunaan media berbasis teknologi informasi dan komunikasi. Kemajuan teknologi dan Internet memang telah banyak mengubah konsep kegiatan dan bisnis tertentu, termasuk dalam pendidikan di Perguruan Tinggi. Sekarang ini telah banyak dosen menawarkan sumber belajar berbasis online. 
Di samping itu, banyak pula penerbit merilis buku online. Berbagai hasil penelitian dalam bentuk artikel ilmiah juga banyak yang diterbitkan dalam bentuk jurnal online. Jumlah informasi yang tersedia secara online melimpah ruah.

Tahun 2016, APJII merilis data bahwa dari 256,2 juta penduduk Indonesia lebih dari setengahnya, yaitu 132,7 juta jiwa menggunakan Internet. Dari komposisi tersebut, sebanyak 10,3 juta $(7,8 \quad \%)$ merupakan mahasiswa dan 8,3 juta $(6,3 \%)$ pelajar. Data tersebut mengungkap bahwa penetrasi penggunaan Internet di area pendidikan cukup tinggi dan terus mengalami peningkatan hingga sekarang.

Memang benar jika menggali informasi atau membaca teks secara online menawarkan sejumlah keuntungan. Misalnya, kemudahan mengakses beragam konten, praktis, meningkatkan kapasitas membaca, fleksibel, dan murah (Fidler, 2004; McPherson, 2005). Namun jangan lupa, Internet juga berpotensi memberi dampak negatif pada memori jangka pendek dan memori jangka panjang, seperti menyulitkan konsentrasi dan menghambat pemahaman peserta didik (Leu \& Zawilinski, 2007). Padahal, pendidikan mestinya menumbuhkembangkan tradisi membaca yang mendalam. Membaca secara mendalam di sini berarti melibatkan serangkaian proses yang mendorong pemahaman, termasuk penalaran induktif, deduktif, keterampilan analogis, analisis kritis, refleksi, dan membuka wawasan peserta didik. Lebih dari itu, dalam memilih sumber bacaan itu sendiri kita harus memperhatikan batasan-batasan, standar, dan organisasi yang jelas. Bacaan yang kita pilih tentu merupakan teks yang kualitas dan kesahihan sumbernya dapat dipertanggungjawabkan.

Pada titik inilah kita perlu waspada dari terpaan media digital yang berpotensi mengganggu perkembangan kognitif mahasiswa. Kehadiran media digital yang masif saat ini, di satu sisi, memungkinkan siapa saja memperoleh informasi secara efisien, praktis, fleksibel. Media digital bisa menjadi mode komunikasi yang cepat dan interaktif yang dilengkapi beragam hiburan. Namun, pada aras lain, media online bisa saja kurang cocok untuk kerja kognitif yang memerlukan konsentrasi, proses berpikir bertahap, proses panjang, dan kedalaman pemahaman .

Bila kondisi tersebut terus berlanjut, tentu akan menciptakan apa yang sering kita sebut simpul Gordian. Simpul Gordian adalah keadaan dimana terjadi antinomi ihwal keuntungan dan kerugian penggunaan media online bagi generasi sekarang dan generasi mendatang, yang jika tidak ditangani dengan baik dapat memicu surutnya budaya masyarakat kontemplatif. Terkaman media digital juga dapat secara radikal mengubah cara kita membaca dan memperoleh informasi. Bahkan, ia sangat 
potensial mengubah cara berpikir kita.

Sejalan dengan refleksi itu, Carr (2008), ketika menerbitkan artikelnya Is Google making us stupid? berkata, "saya sulit berkonsentrasi dan mengalami penurunan kemampuan untuk membenamkan diri dalam refleksi kontemplatif terhadap teks yang saya baca di Internet". Walhasil, Carr (2008) berkesimpulan bahwa Internet berpengaruh negatif terhadap kemampuan memahami, konsenterasi dan perilaku membaca.

Menurut Carr (2010), ada semacam paradoks yang muncul mengenai bahan bacaan online. Ia menemukan fakta bahwa saat ini bahan bacaan dianggap bagus hanya diukur berdasarkan jumlah "klik", bukan pada kualitas informasi atau apakah informasi berasal dari sumber valid. Kelihatannya banyak orang yang belum mampu menikmati berkah globalisasi salah satunya dalam hal memanfaatkan kekayaan informasi. Sehingga, meski lingkungan digital menawarkan pelbagai kesempatan yang tak ada habisnya untuk meningkatkan pemahaman melalui kemudahan akses ke segala informasi tentang pengetahuan, kita malah kerap gagal menangkap peluang itu. Hal ini berarti pembaca belum bisa memanfaatkan dukungan web dengan sepenuhnya. Terkadang mereka tidak bisa memilih dan memilah bacaan yang berguna atau yang justru mengganggu. Akibatnya, mereka bisa saja terperosok dalam informasi yang tidak relevan dan tidak terkait dengan apa yang hendak dicari.

Karena itulah, ada minat akademik untuk meneliti bagaimana perilaku membaca mahasiswa di lingkungan digital. Dalam konteks ini, penelitian akan fokus pada mengeksplorasi aktivitas mahasiswa membaca secara offline dan online, serta menganalisis dampak lingkungan online pada perilaku membaca mahasiswa. Seperti yang dikemukakan oleh Carr (2010) dampak dari internet dan membaca online mungkin telah mempengaruhi dan mengubah pola membaca individu. Hasil penelitian ini diharapkan dapat menyumbang pemikiran dalam mempertimbangkan, boleh jadi memperkuat atau justru mengkritisi, penggunaan internet sebagai salah satu media pembelajaran.

\section{METODE}

Subjek penelitian ini mahasiswa pendidikan biologi UIN Raden Intan Lampung. Pendekatan sequential mix method; melibatkan metode penelitian kualitatif dan kuantitatif secara berurutan dipilih sebagai alas prosedur meneliti. Dalam penelitian ini, materi online didefinisikan sebagai materi yang dibaca mahasiswa di layar lewat jaringan internet seperti website, posting blog, jurnal online, surat kabar online, atau materi online yang diund uh seperti jurnal elektronik, dan dokumen lainnya. Sedangkan materi 
offline adalah materi yang dibaca mahasiswa versi cetak.

Langkah pertama, peneliti mengeksplorasi kebiasaan membaca mahasiswa secara umum. Sampling menggunakan teknik bola salju. Pengamatan difokuskan untuk membidik pola dasar perilaku membaca mahasiswa yang ditelusuri dengan kuesioner dan didalami dengan wawancara. Pada penelitian ini, jumlah responden yang berhasil dijaring dan mengisi kuisioner sebanyak 279 orang.

Kedua, perwakilan responden yang dipilih secara proporsional dibentuk 2 kelompok. Masingmasing kelompok terdiri dari 30 orang. Kelompok A diberi kesempatan membaca materi secara online dan kelompok B membaca secara offline.

Pengumpulan data dilakukan dengan teknik tes dan non tes. Mulamula undangan kesediaan menjadi responden didistribusikan melalui $e$ mail, media sosial: Facebook dan Whatsapp atau diberikan secara langsung kepada responden. Survei ini dikerjakan secara efektif selama 15 hari.

Dalam membandingkan tingkat pengetahuan dan pemahaman, responden yang telah dikondisikan dalam 2 kelompok berbeda diberikan kesempatan membaca masing-masing satu minggu untuk membaca online dan offline. Materi bacaan mahasiswa disajikan dibatasi pada topik desain penelitian eksperimental, desain penelitian kualitatif, dan desain penelitian korelasional. Responden dibebaskan untuk memilih tempat dan waktu yang mereka sukai untuk membaca dengan catatan mereka secara rutin mencatat durasi membaca. Setelah mahasiswa menyelesaikan tugas membaca selama masing-masing 1 minggu/topik, mereka diuji untuk mengukur pengetahuan dan pemahamannya terhadap teks dengan tes tertulis. Kemudian, data penelitian yang terkumpul dianalisis sesuai tema dan sub tema masingmasing dipandu pertanyaan penelitian.

\section{HASIL DAN PEMBAHASAN}

Bagian ini disusun sebagai berikut. Pertama, profil perilaku membaca mahasiswa secara umum baik secara online maupun offline. Setelah itu diikuti penjelasan yang menggambarkan tentang pengaruh membaca materi online dan offline terhadap pengetahuan dan pemahaman mahasiswa.

\section{Profil perilaku me mbaca mahasis wa secara umum}

Hasil survei memperlihatkan bahwa mahasiswa cenderung memilih kedua media membaca secara bersamaan, online dan offline. Mereka memilih dan mengutamakan membaca secara offline ( $p$-book) untuk membaca materi perkuliahan. Bagi mahasiswa, membaca materi perkuliahan dari buku lebih membuat paham secara utuh. Dengan membaca dari buku cetak mereka bisa membaca materi dengan lebih 
fokus, lengkap, dan jelas. Mereka juga bisa membuat batasan-batasan yang jelas sampai sejauh mana mereka membaca dengan memberi marka, atau bahkan mereka bisa memberi tanda-underline, melipat, memberi warna tebal, menempelkan kertas "post it" lalu memberi catatan, atau memberikan catatan kecil pada bagian penting. Para mahasiswa lebih suka membaca buku cetak karena menganggap membaca materi yang tersedia online lebih membingungkan. Itu karena mereka hanya membaca secara singkat dan acak. Bahkan pernah suatu waktu mereka hanya membaca sekilas materi yang mereka cari, lalu di-copy paste untuk membuat tugas mata kuliah.

Di sisi lain mereka pun suka membaca secara online. Alasan yang sering muncul antara lain: mahasiswa tidak memiliki buku yang terkait materi yang ingin mereka baca, lebih mudah baca online, materi tersedia melimpah, bahan bacaan bervariasi, biaya murah (tidak harus beli buku), dan lebih up-to-date. Sayangnya ketika ditelisik lebih jauh, banyak mahasiswa yang kerap tersesat pada pencarian bahan bacaan yang kredibiltasnya meragukan, misalnya blogspot. Ini karena mereka hanya mengandalkan judul besar sebagai kata kunci saat melakukan pencarian. Hampir seluruh mahasiswa tidak tahu website yang dapat dikunjungi untuk kebutuhan akademik. Adapun beberapa yang mereka tahu kadangkala berbahasa asing dan mereka mengalami kesulitan untuk menerjemahkannya.

Mahasiswa membaca secara online atau offline memang tidak hanya untuk keperluan akademik saja. Karena itu, penelitian ini juga mengamati perilaku mahasiswa dalam membaca secara umum. Meskipun, kami mengidentifikasi bahwa paling banyak mahasiswa membaca dengan media online dan offline untuk kebutuhan mencari sumber belajar.

Saat ditelusuri lebih lanjut, diketahui bahwa mayoritas mahasiswa lebih banyak membaca secara online. Alasannya media online lebih menjanjikan kepraktisan, efesiensi waktu, biaya lebih murah, kemudahan, ketersediaan bahan bacaan. Sedangkan mahasiswa yang memilih membaca offline umumnya karena ingin mencari inspirasi, menghabiskan waktu, mencari hiburan, karena memiliki buku, pilihan gaya hidup, kemudahan. Berikut ini ditampilkan Tabel 1. yang menggambarkan alasan mahasiswa membaca. 
Tabel 1. Alasan Mahasiswa Membaca.

\begin{tabular}{clccc}
\hline No & \multicolumn{1}{c}{ Aspek yang dianalisis } & Offline & Online & Jumlah \\
\hline 1 & Untuk mencari informasi & 76 & 275 & 351 \\
2 & Untuk belajar & 129 & 166 & 295 \\
3 & Untuk hiburan & 84 & 210 & 294 \\
4 & Untuk memperbaiki suasana hati & 92 & 179 & 271 \\
5 & Karena kemudahan akses bahan bacaan & 51 & 218 & 269 \\
6 & Karena tidak harus ke perpustakaan & 45 & 222 & 267 \\
7 & Karena ketersediaan bahan bacaan & 111 & 156 & 267 \\
8 & Karena tidak perlu berinteraksi dengan & 136 & 124 & 260 \\
& orang lain & & & \\
9 & Agar tidak merasa jenuh & 91 & 168 & 259 \\
10 & Untuk penghargaan terhadap diri sendiri & 148 & 111 & 259 \\
11 & Karena hemat biaya & 154 & 104 & 258 \\
12 & Karena hemat waktu & 89 & 167 & 256 \\
13 & Sebagai gaya hidup & 110 & 141 & 251 \\
14 & Untuk mengisi waktu luang & 115 & 131 & 251 \\
15 & Untuk bisa mengontrol perilaku membaca & 134 & 112 & 246 \\
16 & Karena tidak harus mengembalikan buku & 37 & 208 & 245 \\
17 & Karena memungkinkan interaksi dengan & 121 & 123 & 244 \\
& bacaan & & & \\
18 & Karena ingin memiliki ruang personal (ingin & 105 & 119 & 224 \\
& sendiri) & & & \\
\hline & & & & \\
\hline
\end{tabular}

Sebanyak 351 responden menyatakan mencari informasi sebagai alasan paling utama mengapa mereka membaca. Dari respon itu, mayoritas mahasiswa memilih membaca secara online sebagai pilihan utama sementara yang memilih mencari informasi secara offline atau cetak jauh lebih sedikit. Membaca untuk belajar dan mencari hiburan diakui sebagai motif tertinggi kedua alasan mereka membaca. Menariknya, untuk aspek membaca untuk belajar para mahasiswa cenderung memilih media online. Aspek membaca untuk memperbaiki mood, aksesibilitas, dan ketersediaan bahan bacaan adalah alasan paling populer berikutnya untuk membaca. Sangat menarik dan penting untuk dicatat bahwa lebih banyak responden memilih membaca secara online daripada offline dalam bermacam alasan. Hal ini mengindikasikan bahwa media baca online mendominasi pilihan mahasiswa untuk membaca buku. memilih media online. Aspek membaca untuk memperbaiki mood, aksesibilitas, dan ketersediaan bahan bacaan adalah alasan paling populer berikutnya untuk membaca. Sangat menarik dan penting untuk dicatat 
bahwa lebih banyak responden memilih membaca secara online daripada offline dalam bermacam alasan. Hal ini mengindikasikan bahwa media baca online mendominasi pilihan mahasiswa untuk membaca buku.

\section{Membaca secara offline (cetak)}

Buku merupakan jenis bahan bacaan offline/berbasis cetak yang paling banyak dibaca oleh mahasiswa. Berdasarkan respon mahasiswa yang disurvei diketahui rata-rata mereka menghabiskan waktu 4,6 jam per minggu untuk membaca buku. Di samping itu, mahasiswa menyatakan bahwa mereka menghabiskan 1,3 jam per minggu untuk membaca majalah.

Koran paling sedikit dibaca oleh mahasiswa. Mahasiswa menghabiskan rata-rata 0,32 jam per minggu untuk membaca koran. Sejumlah mahasiswa memilih opsi "lain" dan menyebutkan beberapa jenis bahan bacaan offline lainnya. Namun, paling banyak dari mereka menyatakan membaca materi yang berkaitan dengan perkuliahan secara offline, misalnya jurnal.

Sebanyak 215 mahasiswa menyebutkan bahwa rumah adalah lokasi utama untuk membaca secara offline atau cetak. Rata-rata mahasiswa menghabiskan 3,3 jam per minggu untuk membaca di rumah. Kampus merupakan tempat paling umum kedua untuk membaca dan 145 mahasiswa menyatakan bahwa mereka menghabiskan sekitar 2,7 jam per minggu untuk membaca di kampus. Sebagian kecil mahasiswa menyatakan biasa membaca di perjalanan dan mereka menghabiskan rata-rata 0,15 jam per minggu untuk membaca secara offline.

Ditinjau dari segi waktu, mahasiswa membaca secara offline atau cetak secara tersebar sepanjang hari. Paling banyak mahasiswa membaca pada waktu istirahat. Sedikit mahasiswa membaca di waktu sore hari. Bila melihat pola waktu membaca mahasiswa, umumnya mereka membaca di waktu istirahat, di malam hari, dan menjelang tidur. Jika dikaitkan antara waktu mahasiswa membaca dengan jumlah jam membaca perminggu dapat kita duga bahwa membaca bukan merupakan aktivitas primer bagi mahasiswa.

Untuk mengungkap cara mahasiswa membaca secara offline, dilakukan survei terhadap perilaku cara membaca mereka. Dari 300 jawaban, $\quad 166$ mengindikasikan bahwa mahasiswa membaca secara offline dari awal hingga akhir. Membaca dengan memilih bagian menarik saja untuk dibaca dipilih sebagai pola membaca paling umum kedua. Sebanyak 33 peserta, yaitu $11 \%$ dari total responden, menunjukkan bahwa mereka membaca dengan cepat dan meloncat-loncat (skimming). Sebagian kecil responden menunjukkan bahwa mereka membaca bagian awal dan melompat ke bagian terakhir dari isi bacaan. Dari total responden, 0,23\% memilih 
opsi "lainnya" dan menyatakan bahwa perilaku membaca mereka bergantung pada isi atau materi yang mereka baca.

\section{Membaca secara online}

Mahasiswa membutuhkan perangkat untuk mengakses materi online, tujuan dari pertanyaan pertama adalah untuk menggali informasi tentang perangkat apa yang digunakan mahasiswa. Dari 297 responden, 85,5\% melaporkan bahwa mereka menggunakan smartphone untuk membaca konten online. Laptop adalah perangkat kedua yang paling sering digunakan dan 12,8\% responden menggunakannya. Hanya ada 5 responden $(0,17 \%)$ yang membaca konten online mengguakan komputer.

Selanjutnya, responden memberikan gambaran yang baik tentang jenis materi yang mereka baca secara on line. Sebanyak 43,34\% mahasiswa menyatakan halaman web sebagai jenis bacaan online yang paling sering dibaca. Rata-rata, mahasiswa menghabiskan 7,13 jam per minggu untuk membaca halaman web seperti wiki, blog, google search dan forum online. Buku elektronik (e-book) menempati urutan kedua materi online yang paling sering dibaca dan mahasiswa rata-rata menghabiskan 4,82 jam per minggu. Bahan bacaan yang paling sering dibaca di urutan ketiga adalah surat kabar online. Rerata mahasiswa menghabiskan 1,60 jam per minggu untuk membaca berita online. Paling sedikit mahasiswa membaca majalah online. Mahasiswa menghabiskan
1,07 jam per minggu saja untuk membaca majalah online. Beberapa mahasiswa juga menyatakan membaca materi online selain yang tercantum dalam daftar jawaban, antara lain jurnal, makalah, dan materi-materi perkuliahan lainnya.

Berkenaan dengan lokasi mahasiswa membaca materi online, responden memperlihatkan bahwa mereka paling banyak menghabiskan waktu untuk membaca materi online di rumah. Jumlah rata-rata jam per minggu adalah 7,9. Sejumlah responden (212) memilih rumah sebagai tempat paling umum untuk membaca secara online dibandingkan dengan di kampus (115 responden). Jumlah jam yang mereka habiskan untuk membaca di kampus 4,77 jam per minggu. Sebagian kecil lainnya (60 responden) biasa membaca konten online dalam perjalanan dalam durasi rata-rata 2,52 jam per minggu.

Waktu digunakan mahasiswa untuk membaca konten online tersebar sepanjang hari. Mayoritas responden lebih suka membaca konten online di waktu istirahat dan malam hari. Sebanyak 160 mahasiswa menyatakan bahwa mereka membaca di waktu istirahat dan 161 melaporkan bahwa mereka membaca di malam hari. Kebanyakan mahasiswa juga menyatakan bahwa mereka lebih suka membaca online saat menjelang tidur (80 responden).

Cara mahasiswa membaca konten online tak jauh berbeda dengan cara mereka membaca konten 
secara offline. Pola membaca yang paling sering dipilih adalah cara membaca dari awal sampai akhir dan kebanyakan mahasiswa hanya membaca konten yang menarik bagi mereka. Sebanyak $159 \quad(51,79 \%)$ mahasiswa memilih membaca dari awal sampai akhir. Mahasiswa yang memilih membaca pada bagian yang menarik bagi mereka saja sebanyak 96 (31,27\%). Sebagian besar mahasiswa mengungkapkan bahwa mereka lebih suka mencetak materi untuk dibaca.

\section{Perbandingan perilaku membaca online dan offline}

\section{a. Pemahaman}

Dari total jumlah responden, 13 mahasiswa menyatakan bahwa tingkat pemahaman mereka ketika membaca offline sangat tinggi. Sebanyak 137 responden lainnya melaporkan tingkat pemahaman mereka tinggi dan 97 melaporkan rendah. Hanya 6 responden yang melaporkan tingkat pemahaman sangat rendah. Sementara itu, 16 mahasiswa mengutarakan bahwa tingkat pemahaman mereka ketika membaca online sangat tinggi. 152 responden lainnya menyatakan tingkat pemahaman mereka tinggi dan 97 menyatakan tingkat pemahaman mereka rendah.

Ketika mempertimbangkan tingkat pemahaman mahasiswa saat membaca konten online, terlihat sebagian besar mereka menyatakan memiliki tingkat pemahaman yang lebih tinggi daripada membaca offline. Namun, dapat dilihat bahwa ada pergeseran nyata ketika mengkaji aspek konsentrasi. Sebagian besar mahasiswa justru merasa lebih konsentrasi ketika membaca secara offline.

\section{b. Konsentrasi}

Dari sejumlah responden yang disurvei, 149 mahasiswa menyatakan bahwa mereka memiliki tingkat konsentrasi tinggi dan 11 sangat tinggi saat membaca online. 108 mahasiswa menyatakan tingkat konsentrasi mereka rendah saat membaca konten online. Hanya 1 yang menyatakan sangat rendah. Dalam hal membaca offline, 154 mahasiswa menyatakan bahwa tingkat konsentrasi mereka tinggi saat membaca secara offline. Ada 16 mahasiswa menyatakan sangat tinggi. Sementara, sebanyak 77 mahasiswa memiliki tingkat konsentrasi rendah dan tidak ada responden yang menyatakan memiliki tingkat konsentrasi sangat rendah saat membaca offline.

\section{c. Daya Serap}

Dari semua 266 responden, 150 orang menyatakan bahwa mereka memiliki tingkat penyerapan konten yang tinggi dengan membaca secara online. Sebanyak 13 responden memilih sangat tinggi. 101 responden merasa membaca secara online memberi kontribusi daya serap rendah. Dan, hanya 2 responden mengatakan daya serap mereka sangat rendah ketika membaca secara online.

Sebagai perbandingan, 140 responden memiliki tingkat penyerapan konten tinggi saat membaca secara offline. Ada 13 
responden yang mengakui memiliki tingkat penyerapan konten yang sangat tinggi. Sebanyak 89 peserta memiliki tingkat daya serap konten yang rendah. Hanya 1 responden yang mengaku memiliki daya serap sangat rendah saat membaca secara offline. Secara keseluruhan, terbukti bahwa responden memiliki tingkat daya serap yang lebih tinggi ketika membaca secara offline dibandingkan dengan membaca secara online.

\section{d. Daya Ingat}

Secara umum, responden menunjukkan bahwa mereka memiliki daya ingat tinggi terhadap konten saat membaca offline. Sebanyak 138 responden menyatakan bahwa mereka memiliki daya ingat tinggi bila membaca offline. Ada 7 responden mengungkapkan daya ingat mereka sangat tinggi. Sementara itu, sebanyak 86 mengaku daya ingat mereka rendah dengan membaca offline dan tidak ada responden yang memiliki daya ingat sangat rendah saat membaca offline.

Terkait dengan membaca online, sebanyak 131 responden melaporkan memiliki daya ingat tinggi saat membaca online. Ada 10 responden menyatakan sangat tinggi, dan 105 responden mengaku rendah dalam hal daya ingat mereka saat membaca online. Ada 2 responden yang menyatakan memiliki daya ingat sangat rendah. Dari uraian tersebut, responden memiliki kemampuan mengingat konten yang lebih baik jika mereka membaca secara offline daripada online.

\section{Pengaruh Internet Terhadap Pengetahuan dan Pemahaman}

Untuk melihat lebih jauh pengaruh internet pada perilaku membaca mahasiswa terkait pengetahuan dan pemahaman mereka pada materi tertentu, maka dilakukan komparasi hasil tes. Hasil tes pengetahuan (C1) dan pemahaman (C2) mahasiswa yang membaca secara online $(\mathrm{N}=30)$ dan offline $(\mathrm{N}=30)$, pada materi metode penelitian pendidikan. Ada perbedaan cukup mencolok level pemahaman mahasiswa yang membaca secara online dan offline. Mahasiswa yang membaca materi secara offline memperoleh nilai ratarata pemahaman lebih tinggi dibandingkan dengan mahasiswa yang membaca secara offline.

Setelah dilakukan uji t, dapat diketahui bahwa terdapat perbedaan signifikan pada aspek pemahaman antara mahasiswa yang membaca online dan offline. Tabel 2. berikut ini menampilkan nilai hasil uji t. 
Tabel 2. Hasil Uji t

\begin{tabular}{|c|c|c|c|c|c|}
\hline Media & Aspek & Rata-rata & Nilai sig & nilai $\alpha$ & Kesimpulan \\
\hline Online & $\mathrm{C} 1$ & 66,25 & 0017 & \multirow{4}{*}{0,05} & \multirow{4}{*}{$\begin{array}{c}\text { Berbeda } \\
\text { signifikan }\end{array}$} \\
\hline Offline & (Pengetahuan) & 81,05 & 0,017 & & \\
\hline Online & $\mathrm{C} 2$ & 35,77 & \multirow{2}{*}{0,039} & & \\
\hline Offline & (Pemahaman) & 54,11 & & & \\
\hline
\end{tabular}

Penelitian ini memberikan wawasan yang menarik tentang bagaimana perilaku membaca mahasiswa secara online dan offline. Alih-alih memungkiri peran internet yang sangat sentral bagi perkembangan ilmu pengetahuan yang menyediakan seabrek kemudahan, penelitian ini justru mengambil secuil sisi, yaitu kritik bagi orang-orang yang tidak berhasil menikmati berkah kemajuan teknologi. Untuk itu, bagian pembahasan ini lebih ingin menyajikan pandangan peneliti yang boleh jadi berlawanan dengan perspektif lain. Ringkasnya, pembahasan ini mengajak diskusi yang luas dan multiperspektif yang arahnya untuk memahami pola, bukan untuk mengidealisasi.

Temuan penelitian ini mengungkap bahwa waktu yang dihabiskan mahasiswa untuk membaca secara online meningkat. Para mahasiswa yang disurvei memperlihatkan bermacam pola yang unik baik ketika membaca secara online maupun offline. Satu hal yang perlu dibubuhi catatan, membaca bukanlah suatu aktivitas primer yang dilakukan mahas is wa.

Terkait tingkat pemahaman, konsentrasi, daya serap, dan daya ingat sangat tergantung persepsi masing-masing mahasiswa.

Sebaliknya, kenyamanan dalam membaca dipengaruhi media baca. Meskipun pengembangan dan distribusi berbagai perangkat teknologi yang menyediakan materi secara online, tapi sebagian besar mahasisawa tetap memilih media offline (versi cetak) untuk dibaca.

Saat ini, sebagian besar sumber belajar berupa materi-materi perkuliahan tersedia atau disimpan dalam bentuk digital. Kampus seakan menjelma toko online yang menawarkan lebih banyak materi online. Penerbit-penerbit buku pun mulai gemar merilis buku dan jurnal online. Ditambah lagi, banyak orang yang membuat tulisan-tulisan yang diposting di media online (mis. website, blogspot). Oleh karena itu, jumlah informasi digital terus meningkat. Meningkatnya informasi itu secara langsung atau tidak langsung memaksa orang untuk membaca lebih banyak pada media online. Materi yang disediakan secara online juga memungkinkan lebih banyak peluang dalam mengakses informasi lebih lanjut karena hyperlink. Telah diketahui, jumlah rata-rata tautan dalam suatu materi online adalah 22 dengan kisaran dari 1 hingga 81. Senapas 
dengan itu, materi online memiliki rata-rata 53. Ini berarti bahwa ketika seorang mahasiswa mengakses materi secara online, dia memiliki kesempatan untuk mengakses beberapa dokumen lain yang relevan pada saat yang bersamaan.

Hadirnya teknologi seluler yang sudah sangat dekat dengan kehidupan mahasiswa, membuat informasi lebih mudah diakses. Kini, ponsel telah menjadi bagian gaya hidup mahasiswa. Mahasiswa sudah mulai menggunakan iPhone dan iPod untuk mengakses informasi kapan saja. Perangkat baru ini memiliki karakteristik gabungan dari e-reader, serta komputer pribadi/laptop, dan telepon seluler.

Bila ditelisik lebih jauh, belajar adalah alasan tertinggi kedua yang mendorong peningkatan aktivitas mahasiswa membaca. Materi perkuliahan merupakan sasaran utama bacaan maereka. Fakta lain yang perlu dicatat adalah bahwa mahasiswa dihadapkan dengan volume dan variasi informasi. Seberapa banyak, dan berapa lama mereka memilih untuk membaca adalah keputusan yang sangat penting, mengingat fakta bahwa mereka tidak dapat menambah waktu untuk membaca tanpa batas.

Manakala kita menengok ke belakang, masa sebelum revolusi industri, orang-orang biasa membaca secara intensif. Jumlah materi yang mereka miliki sangat terbatas sehingga mereka membacanya berulang kali. Sejak itu, orang sudah mulai membaca banyak hal. Mereka membaca semua jenis bahan: buku, majalah, surat kabar, dan membaca hal-hal hanya sekali sebelum melanjutkan ke item berikutnya. Saat ini, ada banyak sekali buku, jurnal, dan majalah yang memberi pembaca kesempatan untuk memilih apa yang ingin mereka baca dan bagaimana mereka ingin membaca. Oleh karena itu, pembaca hari ini memiliki berbagai pilihan dalam hal bahan bacaan.

Pada saat melakukan aktivitas membaca offline, mahasiswa memiliki peluang membubuhkan keterangan ketika mereka membaca, terutama ketika mereka hendak membaca secara mendalam. Dalam kegiatan membaca secara offline, memberikan tanda berupa garis tebal, garis bawah, catatan kecil, menempelkan kertas post it, dan mewarnai dengan stabilo pada bagian-bagian yang dianggap penting, adalah aktivitas yang sering dilakukan ketika membaca buku. Sebaliknya, aktivitas tersebut akan lebih sulit dilakukan ketika membaca secara online.

Di sisi lain, kadangkala muncul kekhawatiran manakala semakin banyak bahan bacaan online. Bagaimana masa depan buku cetak? Berbagai hasil studi mengungkapkan kesimpulan bervariasi. Ada beberapa pendapat bahwa buku cetak mungkin akan tergilas kemajuan teknologi digital. Namun, temuan dari penelitian ini mengungkapkan bahwa membaca offline (buku cetak) masih sangat disukai, atau setidaknya mahasiswa 
punya kecenderungan memilih kedua media membaca: online dan offline.

Hadirnya media digital telah mengubah cara mahasiswa membaca. Konten online telah mengambil porsi waktu membaca mahasiswa secara signifikan. Waktu yang seharusnya mereka habiskan untuk membaca buku cetak sebagian besar tersedot untuk membaca konten online. Alasannya jelas, karena sebagian besar bahan bacaan tersedia dalam bentuk online, maka tidak sulit membayangkan bahwa penelusuran bacaan secara online menjadi pola baca utama saat ini. Untuk itu, dengan semakin banyak waktu yang dihabiskan untuk membaca materi online, perilaku membaca pada layar ponsel mulai muncul (Liu, 2005). Dalam penelitian ini beberapa karkteristik perilaku membaca yang dapat diungkap antara lain: pola membaca skim, meloncat-loncat, cepat, memilih membaca bagian awal dan akhir saja.

Salah satu peluang dampak negatif dari perilaku membaca online adalah bergesernya pola membaca alami dan mendalam. Mahasiswa kehilangan ruang untuk membaca secara khusuk (kontempelatif). Beberapa mahasiswa mengungkapkan bahwa mereka menjadi gelisah saat membaca online. Di lingkungan membaca online, mereka membaca potonganpotongan kecil materi belaka dan cenderung melewatkan materi yang berisi paragraf panjang. Nicholas Carr (2008) juga berpendapat bahwa dia tidak bisa lagi membaca secara dalam di lingkungan baca online dan justru terus terrseret untuk menelusur hal-hal lain. Memperkuat argumen Nicholas Carr tersebut, beberapa mahasiswa juga menunjukkan perilaku serupa ketika membaca konten secara online.

Terkait gangguan dalam membaca, media membaca online menyumbang pengaruh gangguan lebih tinggi dibandingkan dengan media offline. Munculya link game, bermacam inforgrafis, video, dan iklan-iklan adalah beberapa yang paling kuat mengganggu mahasiswa saat membaca konten online. Meskipun demikian tak bisa dinafikan bahwa beberapa mahasiswa merasa tidak tidak terganggu.

Yang perlu dibicarakan lebih jauh adalah mengenai berkembangnya hyperlink. Hyperlink memiliki efek mata pisau pada fokus pembaca. Di satu sisi, hyperlink sangat bermanfaat untuk menghubungkan semua konten yang relevan. Namun, di sisi lain, ia juga mungkin akan membuat mahasiswa makin tersesat pada penelusuran konten yang tidak penting. Lagi-lagi, dibutuhkan sikap kritis dan kejelian dalam mengakses konten online.

Tujuan membaca, waktu yang tersedia, dan kredibilitas sumber data adalah alasan utama. mahasiswa memilih jenis bacaan. Kredibilitas sumber informasi sangat mempengaruhi pilihan orang membaca. Bentuk atau format konten online dalam web dirancang dan ditata juga mendorong perilaku 
membaca pembacaan non linier dan selektif. Ringkasnya, bahwa pertumbuhan informasi yang tersedia mempengaruhi perilaku mahasiswa untuk lebih selektif memilih jenis konten yang mereka baca.

Dalam penelitian ini, mahasiswa mengungkapkan tingkat pemahaman mereka lebih tinggi pada media baca offline dibandingkan ketika membaca secara online. Meski demikian ada pula mahasiswa yang capaian yang sama untuk materi online. Media dan konten online yang kaya hyperlink mendorong lebih banyak perilaku membaca tidak linear dan berpotensi mahasiswa membaca secara meloncat-loncat. Semakin banyak tautan yang ditemukan mahasiswa ketika membaca, semakin besar potensi perubahan pada perilaku membaca (Liu, 2005). Hasilnya, terbentuk perilaku membaca yang terfragmen-fragmen dan lebih dangkal.

Sebagaimana telah diutarakan sebelumnya, dengan perilaku membaca cepat, mahasiswa hanya sedikit sekali menghabiskan waktu untuk membaca di lingkungan online. Mereka juga minim kesempatan untuk berpikir mendalam tentang isi bacaan mereka. Perilaku tersebut mengakibatkan tingkat pemahaman mahasiswa lebih rendah.

$\begin{array}{cr}\text { Rendahnya } & \text { tingkat } \\ \text { konsentrasi membaca pada }\end{array}$
lingkungan baca online juga terlihat dari temuan penelitian. Alih-alih bisa fokus membaca konten pada media online, mahasiswa mengaku memiliki tingkat konsentrasi tinggi atau sangat tinggi saat membaca bahan secara offline. Senapas dengan temuan itu, pembaca memang sangat sulit untuk mencurahkan perhatian penuh pada bacaan online karena mereka harus memutuskan teks mana yang akan dibaca, tautan mana yang harus diikuti, dan apakah akan menggulirkan halaman ke bawah atau tidak.

Seterusnya, mahasiswa menyatakan bahwa mereka lebih memilih membaca materi secara offline dibandingkan dengan materi online bila dihubungkan dengan aspek konsentrasi. Lebih tegas lagi mahasiswa berdalih merasa terganggu oleh hal-hal lain seperti email, berita, notifikasi, dll. tatkala membaca di lingkungan online. Harihari ini, ada banyak halaman web dan aplikasi komputer yang menawarkan pemberitahuan po-pup. Fitur-fitur ini boleh jadi sangat bermanfaat tetapi di saat yang sama tampil sebagai momok yang menyebalkan. Animasi, gambargambar (sebagian berupa konten porno) yang muncul secara terusmenerus atau muncul tiba-tiba dapat mengalihkan perhatian dan mengganggu konsentrasi. Meskipun beberapa orang berpendapat bahwa mereka tidak begitu terpengaruh oleh hal-hal tersebut.

Yang patut dibubuhi catatan, temuan penelitian ini dapat menggambarkan perubahan perilaku membaca yang unik. Kami menemukan semacam efek domino 
dalam perilaku mahasisiwa yang membaca di lingkungan online. Akibat rendahnya konsentrasi saat membaca, daya serap mahasiswa juga rendah, dampaknya pengetahuan dan pemahaman mereka turut rendah.

Memang seperti itu biasanya. Daya serap terhadap konten hampir selalu berkorelasi dengan konsentrasi dan pemahaman. Hasil pemeriksaan data survei memperlihatkan bahwa mahasiswa memiliki tingkat daya serap, daya ingat, dan pemahaman yang tinggi ketika membaca secara offline. Namun perlu dicatat pula, ada sejumlah mahasiswa mengaku memiliki daya serap dan pemahaman yang lebih baik di lingkungan online.

Ketika temuan ini diamati, terungkap bahwa mahasiswa membaca di lingkungan online cenderung membaca cepat, memindai bagian-bagian penting saja, dan kurang fokus memperhatikan konten yang mereka baca. Pola membaca ini tentu tidak memungkinkan mahasiswa untuk menyerap banyak konten yang mereka baca karena kurangnya investasi waktu untuk membaca dan berpikir secara mendalam. Akibatnya, jumlah informasi yang dapat dipahami mahasiswa akan menjadi rendah. Tak tersedianya ruang untuk membubuhi keterangan atau menandai bagian penting dari konten yang dibaca juga bisa jadi alasan mengapa daya serap konten lebih sedikit.

Karena tingkat daya serap terhadap konten yang dibaca secara online lebih rendah, tingkat pemahaman mereka tampaknya akan lebih rendah pula. Sementara sebagian besar mahasiswa yang disurvei memiliki tingkat daya serap, daya ingat, dan pemahaman yang tinggi pada media baca offline. Sebaliknya, mahasiswa menyatakan memiliki tingkat daya serap, daya ingat, dan pemahaman lebih rendah di lingkungan baca online. Banyak mahasiswa dapat mengingat lebih baik ketika membaca buku cetak. Mereka dapat fokus membaca materi, dan tidak terganggu oleh hyperlink atau iklan yang biasanya ada dalam konten online.

Dalam sebuah diskusi yang lebih jauh, sejumlah mahasiswa memperlihatkan perilaku yang khas ketika membaca offline. Hal-ihwal fisik dari buku rupanya juga membantu mereka memahami konten dalam tempo cukup lama. Dengan membaca buku cetak mahasiswa dapat mengingat konten beberapa bulan kemudian, sebagian karena dibantu dengan mengingat bentuk, warna, ukuran, ketebalan buku. Sebaliknya, kesan itu tidak dapat dialami ketika membaca secara online. Kebiasan bersentuhan langsung dengan buku saat membaca kelihatannya dapat membantu menerangkan mengapa orang cenderung dapat menyerap dan mengingat konten lebih banyak ketika membaca buku cetak. Untuk memandang hubungan tersebut sepertinya kita patut mengimani pandangan yang mengungkapkan bahwa sistem saraf manusia memiliki 
mekanisme kontrol khusus untuk koordinasi tangan dengan fokus otot mata.

Oleh karena itu, meskipun mahasiswa mengakui bahwa mereka membaca lebih banyak secara online, tingkat penyerapan dan pemahaman mereka tampaknya rendah. Untuk itulah Coiro \& Dobler (2003) berpendapat bahwa untuk meningkatkan pemahaman konten ketika membaca secara online tetap saja dibutuhkan keterampilan dan strategi baru untuk menggunakan internet secara efektif untuk membaca, memahami, dan mempelajari informasi baru.

Bagian selanjutnya yang tak kalah penting adalah mencoba mengkonfirmasi temuan ini dari sudut pandang teoritis. Perubahan perilaku membaca mahasiswa dalam hal membaca suatu materi dan sejauh mana pemahaman mereka tentang konten yang dibaca sepertinya relevan jika dibicarakan dengan teori pemrosesan informasi dan pemahaman mendalam mengenai kognisi manusia. Oleh karena itu, model pemrosesan informasi dipilih untuk membahas temuan-temuan penelitian ini.

Model pemrosesan informasi menyajikan gambaran yang jelas tentang bagaimana mekanisme penyampaian pesan dan pemrosesannya dalam ruang kognisi seseorang. Atas dasar itulah kita dapat mengungkap alasan-alasan mengapa mahasiswa yang membaca di lingkungan online cenderung memiliki daya serap dan pemahaman yang rendah.

Menurut pandangan Atkinson \& Shriffin (1968), informasi diproses dan disimpan dalam tiga tahap memori: sensoris, jangka pendek, dan jangka panjang. Sensorik adalah bagian dari memori yang menerima semua informasi/stimulus yang dapat dirasakan seseorang lewat panca indera (cahaya, suara, bau, panas, dingin). Tubuh memiliki sel-sel reseptor sensorik khusus yang mentransduksi rangsangan eksternal menjadi informasi yang dapat dipahami otak. Dalam proses transduksi, memori dibuat. Pembentukan memori ini sangat pendek dan berlangsung kurang dari setengah detik untuk penglihatan dan sekitar tiga detik untuk pendengaran. Memori jangka pendek, yang juga disebut memori kerja, adalah bagian dari memori di mana informasi baru disimpan sementara sampai kemudian hilang atau diteruskan ke dalam memori jangka panjang. Memori ini awalnya akan berlangsung di suatu tempat sekitar 15 hingga 20 detik kecuali jika diulang, di mana titik itu mungkin tersedia hingga 20 menit. Ada dua konsep utama untuk menyimpan informasi dalam memori jangka pendek: organisasi dan pengulangan. Memori jangka panjang memiliki kapasitas tak terbatas dan menyimpan informasi tanpa batas (Huitt, 2003).

Pada fase-fase pemrosesan informasi, stimulus akan menimbulkan respon memori 
sensorik dan ditransfer ke memori jangka pendek sampai memori dikodekan ke memori jangka panjang atau dilupakan sebagai akibat dari tidak ada pengulangan. Ada banyak teknik untuk meningkatkan penyimpanan informasi dalam memori jangka pendek. Chunking adalah teknik utama untuk mendapatkan dan menyimpan informasi dalam memori jangka pendek; itu juga merupakan jenis elaborasi yang akan membantu mendapatkan informasi ke dalam memori jangka panjang (Huitt, 2003).

Sebagian besar materi yang tersaji pada media online dirancang untuk berukuran kecil. Beberapa konten juga ditata dengan cara yang efektif. Teknik-teknik organisasi ini membantu mahasiswa untuk menyimpan materi dalam memori jangka pendek mereka. Namun, ketika mahasiswa membaca secara meloncat-loncat atau memilih bagian-bagian yang penting saja, mereka cenderung melewatkan beberapa kata, oleh karena itu konten yang diserap ke memori jangka pendek tidak lengkap. Menurut Miller (1956) jumlah unit yang dapat diproses dalam memori jangka pendek adalah $7+2$. Ketika orang cenderung membaca cepat dengan jumlah konten yang cukup banyak, maka jumlah informasi yang diserap melalui memori sensorik dapat dengan mudah melebihi jumlah unit ini. Penting juga untuk dicatat bahwa konten yang diserap ke memori sensorik bisa lebih banyak, tergantung pada apa yang dirasakan reseptor lain pada saat yang bersamaan. Sebagaimana ditunjukkan oleh mahasiswa yang disurvei, gangguan yang terjadi di lingkungan online juga dapat menghambat proses ini.

Selain itu, masalah utama yang menghambat proses memori sensori ke memori jangka pendek sampai kemudian ke memori jangka panjang adalah absennya pengulangan. Sebagian besar mahasiswa memang cenderung hanya membaca satu kali teks yang mereka baca, baik mahasiswa yang membaca secara online maupun offline. Dari sini kita tahu bahwa teknik repetisi juga jarang digunakan oleh mahasiswa. Akibatnya, kemungkinan tingkat daya serap konten dan pemahaman mahasiswa yang lebih besar potensial dimiliki oleh mahasiswa yang membaca offline. Karena, mereka punya peluang lebih banyak untuk mengulang-ulang membaca materi secara fokus.

Di sisi lain, akibat kurang lengkapnya jumlah konten yang dibaca ketika membaca secara online, tentu menjadi biang kesulitan dalam proses koding. Seumpama menyusun puzzle, manakala ada beberapa bagian yang tidak lengkap, puzzle tidak akan tergabung dengan utuh. Inilah yang mungkin bisa menjadi dasar klaim bahwa membaca konten online akan mudah dilupakan.

KESIMPULAN 
Yang paling mendasar dari temuan penelitian ini adalah mahasiswa mengungkapkan memiliki kecenderungan mengombinasi pola membaca mereka, yaitu membaca secara online dan offline secara berdampingan. Mahasiswa mulai menunjukkan kecenderungan perilaku membaca online yang menumbuhkan kebaiasaan membaca cepat dan meloncat-loncat. Namun, minimnya durasi waktu yang disediakan mahasiswa untuk membaca, konsentrasi rendah, perilaku membaca cepat terungkap sebagai perilaku membaca utama mahasiswa. Alhasil, analisis data menunjukkan bahwa sejalan dengan meningkatnya perilaku membaca cepat, meloncat-loncat, menghasilkan rendahnya pemahaman mahasiswa.

\section{SARAN}

Temuan dari penelitian ini dapat memberikan sumbangan pemikiran bagi para akademisi dan praktisi. Studi ini memberikan kontribusi untuk memperluas dan meningkatkan literatur akademik saat ini pada membaca online dengan memberikan daftar situs yang kredibel untuk dikunjungi. Para pendidik dan penulis yang menyampaikan informasi atau menuliskan suatu bahan bacaan di media online dapat mempergunakan temuan ini sebagai bahan pertimbangan saat merancang bahan bacaan. Umpamanya, jangan sampai ketika mengunggah materi-materi perkuliahan di situs web, terganggu oleh hadirnya iklan-iklan. Dan yang mesti dibubuhi catatan adalah bagaimana kita secara bersama-sama menggugah kesadaran agar kita menjadi pembaca yang kritis baik ketika membaca online maupun offline.

\section{DAFTAR RUJUKAN}

Asosiasi Penyelenggara Jasa Internet Indonesia (APJII). 2016. Infografis: Penetrasi dan Perilaku Pengguna Internet Indonesia. APJII. https://apjii.or.id/content/read/1 04/229/Buletin-APJII---Edisi01-September-2016

Atkinson, R. \& Shiffrin, R. 1968. Human Memory: A Proposed System and It's Control Processes. In K. Spence and J. Spence (Eds.). The Psychology of Learning and Motivation: Advances in Research and Theory (2). New York: Academic Press.

Coiro, J. \& Dobler, E. 2007. Exploring the Online Reading Comprehension Strategies Used by Sixth-Grade Skilled Readers to Search for and Locate Information on the Internet. Reading Research Quarterly. 42(2).

Carr, N. 2008. Is Google Making Us Stupid?. The Atlantic Monthly. 302(1), 56-63.

Carr, N. 2010. The Shallows: What the Internet is Doing to Our Brains. W.W. Norton \& Company.

Fidler, M. 2004. Reading and Studying Culture with 
Electronic Materials. Canadian

Slavonic Papers. 46(1/2), 8399.

Huitt, W. 2003. The Information

Processing Approach to

Cognition: Educational

Psychology. Interactive

Valdostaga. Retrieved 29

September 2017, from http://www.edpsycinteractive. org/topics/cogsys/infoproc.html

Leu, D. \& Zawilinski, L. 2007. The New Literacies of Online Reading Comprehension. New England Reading Association Journal. 43(1), 1-7.

Liu, Z. 2005. Reading behaviour in the digital environment:
Changes in reading behaviour over the past ten years. Journal of Documentation. 61(6), 700712.

McPherson, K. 2005. Reading the Internet. Teacher Librarian. 32(5), 60-61.

Miller, G. A. 1956. The magical number seven, plus or minus two: Some Limits on Our Capacity for Information Processing. Psychological Review. 63, 81-97

OECD. 2016. PISA 2015 Result in Focus.

https://www.oecd.org/pisa/pis a-2015- results-in-focus.pdf 